\title{
Enhancing Green Hotel Visit Intention: Role of Green Perceived Value, Perceived Consumer Effectiveness and Environmental Knowledge
}

\author{
Sanjida Amin ${ }^{1}$, Md. Touhiduzzaman Tarun ${ }^{2}$ \\ ${ }^{1}$ Lecturer, Department of Marketing, Faculty of Business Studies, Bangladesh University of Professionals, \\ Bangladesh \\ ${ }^{2}$ Dhaka, Bangladesh \\ Correspondence: Sanjida Amin, Lecturer, Department of Marketing, Faculty of Business Studies, Bangladesh \\ University of Professionals, Bangladesh.
}

Received: March 13, 2019

doi:10.5539/ibr.v12n5p123

\author{
Accepted: April 19, 2019 \\ Online Published: April 26, 2019 \\ URL: https://doi.org/10.5539/ibr.v12n5p123
}

\begin{abstract}
Based on the extensive literature review, this study aims to investigate the impact of green perceived value and perceived consumer effectiveness on customers' green hotel visit intention in the hotel industry of Bangladesh. Simultaneously, the current study intends to explore the influence of environmental knowledge as a moderator. A random sample survey of 265 usable hotel customers was used to test and verify the conceptual framework. The findings of study revealed that green perceived value and perceived consumer effectiveness positively influence customers' green hotel visit intention, whereas, environmental knowledge was found insignificant moderator variable. The outcome of the study will assist the academicians, policy makers and industry professionals with a better understanding of customer green purchase intention. Therefore, the study will contribute to the development of effective green marketing practices and strategies to enhance customer green purchase intention in the hospitality and tourism industry in Bangladesh.
\end{abstract}

Keywords: green perceived value, perceived consumer effectiveness, environmental knowledge, Bangladesh

\section{Introduction}

In this $21^{\text {st }}$ century, the concept of green consumerism and green marketing is very prevailing throughout the world. Though the countries of Asia region have not yet accepted the trend with that much enthusiasm, countries of western region have considered the trend so seriously and started to accept in all areas (Asia's Media \& Marketing Newspaper, 2008). Consumers of western countries specifically the customers of USA and Europe are increasingly growing environmentally responsible showing significant responsible behaviour towards the environment (Curlo, 1999). As the number of Asian consumers are increasing and showing significantly conscious and responsible behaviours towards environmental problems, both local and international green marketers have targeted the large scale Asian customers (Harris, 2006). Consumers of Asian society Researchers defined green marketing as the inclusion of environmental concerns and issues in the marketing activities through the minimization of natural resources (Rex \& Baumann, 2006). Smith (2008) expressed that the term green marketing is one of the notable issue which may assist the organization to sustain in the long run and to compete in this changing arena.

From the organizations perspective, green marketing can help the firm availing new opportunities and gaining a wider range of competitive advantages over the competitors through lowering cost, differentiating and getting focused (Rex \& Baumann, 2006). Again, Siegenthaler (2010) pointed that, green marketing can also modify the actions and behaviours of the customers through renewal energy usage, tree plantation, buying environmentally sustainable products, becoming socially responsible etc. Though the customers of green products and services comprise a significant proportion in the context of Bangladesh and other Asian markets, very few green purchase behaviours are noticed due to the lack of proper knowledge and consumer perceived effectiveness. Understanding consumer green perception based on their attitude, knowledge, value perception, perceived effectiveness, purchase intention and green purchase behaviour is essential and these have been widely discussed by the previous researchers.

Though Environmental sustainability is becoming a major mandate for the organizations around the world, 
hospitality industry has been remaining as a slower sector to respond (Carroll \& Buchholtz, 2014, Millar \& Baloglu, 2011). But researchers argued that the concept of sustainability and ecological is becoming more concerned issue in the context of hospitality industry (Sloan, Legrand \& Simons-Kaufmann, 2014). For the last few years, the concepts like green marketing, environmental responsible marketing, socially responsible marketing etc have been growing significant in the tourism and hospitality industry (Gustin \& Weaver, 1996). Vora (2007) have identified that 43 million U.S. tourists have demonstrated their consciousness towards environment and society. According to Green Hotels Association, 2010, hotels those are conducting their business by minimizing the usage of natural resources and saving the natural resources through efficiency are called green hotels. Wolff (2008) found out several practices essential for the green hotel marketers such as to save water, save energy, reduce the amount of waste, reduce the usage of natural resources, minimize the use of paper, use energy efficient light, use electronics way of communicating instead of paper etc. Therefore, hotel industry is becoming environmental friendly to decrease the negative impact on the environment, to minimize the usage of natural resources and to attract environmentally conscious customers around the world (Han, Hsu \& Sheu, 2010; Jones, Hillier \& Comfort, 2014)

However, as customers are becoming more savvier regarding sustainability, several previous researchers focused on this issue and conducted research on green purchase intention and green purchase behaviour (Chan \& Lau, 2000). Thus, the current study is going to investigate the relationship among green perceived value, perceived effectiveness and intention to visit green hotels. The study will also examine the moderating effect of environmental knowledge on the interaction of these variables which may enhance the level of understanding regarding green purchase intention of the customers in the hotel industry in Bangladesh. Therefore, the objectives of the current study are:

(1) To examine the effect of green perceived values and perceived consumer effectiveness on customer green hotel visit intention;

(2) To investigate whether environmental knowledge moderates the relationship between green perceived value, consumer perceived effectiveness and customers intention to visit green hotels.

\section{Review of the Literature}

\subsection{Green Perceived Value and Visit Intention}

As Customers may make judgment based on several incomplete and referred information, perceived value of any product or services may act as a predictor of customers purchase or visit intention (Kardes, Posavac \& Cronley, 2004). Customers perceived value can be denoted as the perception of the customers about the benefits, attributes and features of a product or service that would significantly increase positive word of mouth and influence customers purchase intentions (Ashton, Scott, Solnet \& Breakey, 2010). Several previous literatures found a positive relation between perceived value and purchase intention (Gounaris, Tzempelikos \& Chatzipanagiotou, 2007). Researchers indicated that perceived value can have a significant positive impact on customers purchase intention and loyalty (Brady \& Robertson, 1999; Cronin, Brady, Brand, Hightower \& Shemwell, 1997). Based on the previous literature studies it can be inferred that customers' perceived value of a particular socially responsible product or services is a new concern in this environmental era and hence researchers concluded that customers are more likely to purchase the product if they perceive higher value of a product or services (Chang \& Chen, 2008). Therefore, from the previous literature it can be asserted that green perceived value can significantly influence customers purchase (visit) intention and the following hypothesis can be drawn:

Hypothesis 1 (H1): Green perceived value is positively associated with customers' hotel visit intention.

\subsection{Perceived Consumer Effectiveness and Visit Intention}

Perceived consumer effectiveness can be defined as the evaluation and judgment of the customers regarding the ability of the customers to address and contribute to the environmental problems (Roberts, 1996). Researcher identified that seven different studies indicated a significant positive relation between perceived effectiveness and customers purchase intention or adoption of environmentally sustainable products or green products and services (Gleim, Smith, Andrews \& Cronin, 2013; Gupta \& Ogden, 2009). It has been argued that as the customers can realize that they can do something about reducing the usage of natural resources and saving the environment, they may find themselves more socially responsible and incorporate them into the purchase decision (Roberts, 1996). Furthermore, Vermeir \& Verbeke, (2008) concluded that a firm level of PCE encourages customers to demonstrate their significant positive attitude and behaviour towards the consumption of sustainable products and services. Hence from the understanding of the previous literature it can be concluded 
that there is a significant positive relation among perceived customers' effectiveness and customer's hotel visit intention.

Hypothesis 2 (H2): customers' perceived effectiveness is positively associated with customers' hotel visit intention.

\subsection{Environmental Knowledge as a Moderator}

Mostafa (2007) defined environmental knowledge as the knowledge of the customers about the environmental issues, ecological systems, impacts of environmental degradation, application of the socially responsible behaviour and perception of the responsibilities. The current study extensively studied the previous literature and found that customer's knowledge about the green concept and environmental issues significantly influence customers purchase intention hence actual purchase decisions (Chan \& Lau, 2000; Eze \& Ndubisi, 2013). Several other studies indicated that lack of customers' knowledge about the environmental issues and responsibilities may negatively affect the green purchase intention and behaviour (Connell, 2010; Padel \& Foster, 2005). Hence from the literature study it can be stated that environmental knowledge is a significant determinant of customers purchase intention and it can be denoted as one of the major predictors of customers green hotel visit intention. Moreover, Fraj-Andrés \& Martínez-Salinas (2007) conducted a research on environmental knowledge and customer ecological behaviour and considered environmental knowledge as a moderator between ecological attitude and green behaviour. Based on the previous literature support, it can be asserted that more information regarding environmental issue may strengthen customers' environmental knowledge which may reinforce customers' behaviour towards green products and services (Smith \& Paladino, 2010). However, the current study is going to consider environmental knowledge as a moderator between green perceived value and hotel visit intention and perceived effectiveness and hotel visit intention.

Hypothesis 3 (H3): Environmental knowledge moderates the relationship between green perceived value and customer intention to visit green hotel.

Hypothesis 4 (H4): Environmental knowledge moderates the relationship between customer perceived effectiveness and customer intention to visit green hotel.

\section{Conceptual Framework}

Based on the previous literature and hypotheses, following conceptual framework is proposed for the current study:

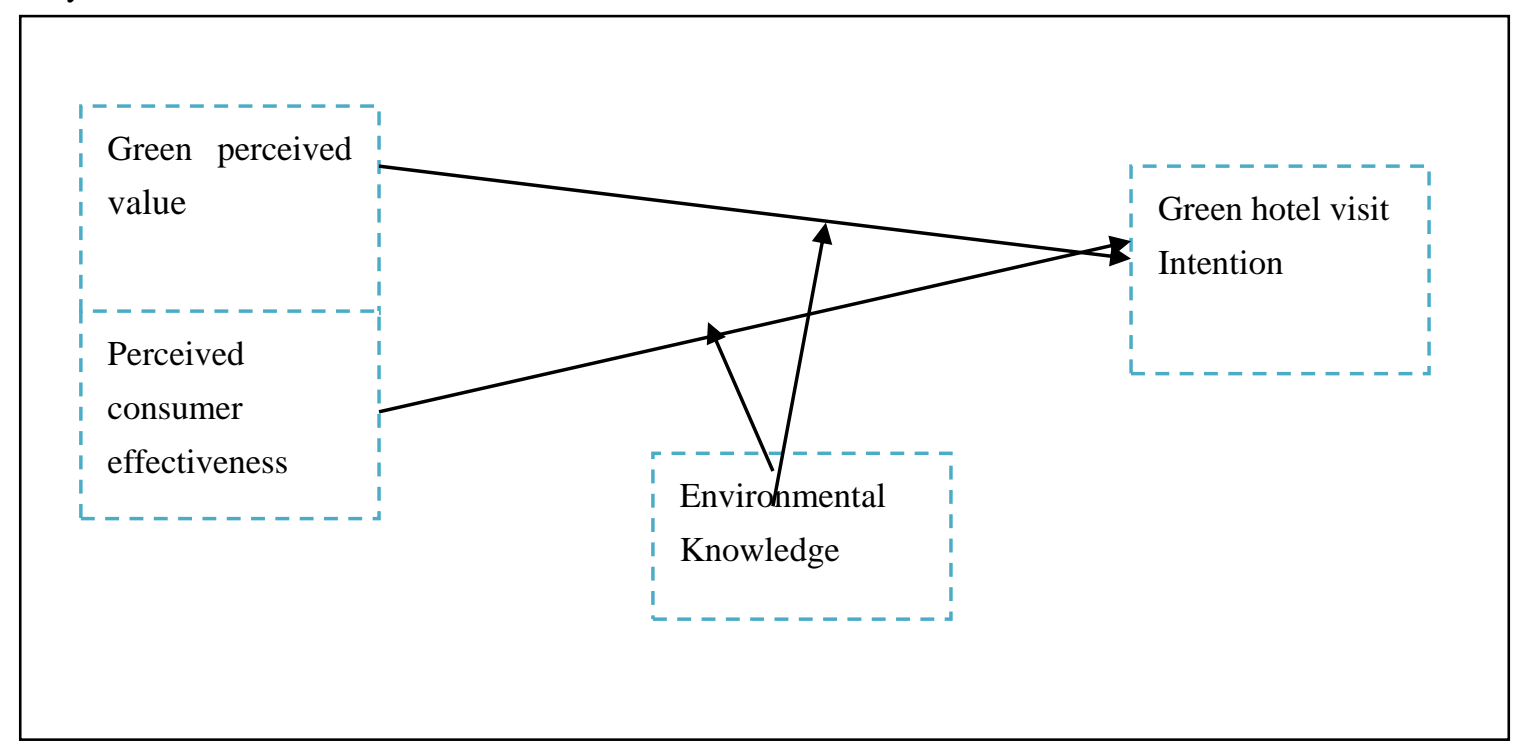

Figure 1. Proposed Research Framework

\section{Research Methodology}

\subsection{Sample and Data Collection}

Customers of hotel industry of Bangladesh were considered as the population of the current study because this particular emerging industry has a significant contribution to the growth of the country. According to the report of Bangladesh Tourism Board (2014) and Bangladesh Parjatan Corporation (2015), the contribution of 
hospitality and tourism industry in Bangladesh is higher than many other Asian countries and it is near about 7.3\% of total gross domestic product (GDP). Another reason for choosing this industry is that customers of hotel industry are growing environmental conscious and socially responsible gradually. Therefore, hotel industry customers are seeking hotels that are following green marketing and eco-friendly approaches (Mankato \& Jauhari, 2007). In this study, three different geographic regions were selected for collecting data such as Dhaka, Chittagong and sylhet. The purpose of this geographic segmentation was to cover the most travelled areas of the countries. As most of the four and five stars hotels in Bangladesh exist in these three regions, these areas are considered as the sampling frame of the study. Study found that approximately $80 \%$ 4-star, and five-star hotels of Bangladesh are located in Dhaka, Chittagong, and Sylhet and rest 20\% are in other areas of Bangladesh (Bangladesh Tourism Board, 2017).

All four star and five-star hotels were considered the sample frame of the current study. It has been identified that these categories of hotels are expected to involve in excessive usage of natural resources leading to more environmental degradation and also these hotels are supposed to be engaged in environmental protection activities (Chou, Chen \& Wang, 2012). Another reason for choosing 4-star and 5-star hotels are that all the 4-star and 5-star hotels are registered which are easier to identify and collect data.

In total there are 13 four and five-star hotels are located in these three regions. As the process of data collection, the researcher communicated with all 13 hotels authority and distributed 500 questionnaires equally through the customer care department and requested to collect the data from the customers. Along with the research questions, a detailed description about the green hotel approaches and strategies was given for the better understanding of the customers.

Among 500 questionnaires, 287 questionnaires were returned from the respondents where 22 were rejected due to incompleteness. Therefore, the researcher found 265 questionnaires usable for analysis with a response rate of 53\% which is significant in the context of Bangladesh found by Rubel \& Kee (2014). Moreover, 100 respondents are sufficient for data analysis by PLS (Hair, Ringle \& Sarstedt, 2013). Therefore, the 265 response is considered sufficient for data analysis.

\subsection{Participant Characteristics}

In the current study, five demographic characteristics, namely, gender, age, marital-status, religion, monthly income and were employed. More than two-third of the respondents (69 per cent) were male. More than one-third of the respondents (45.5) were found age between 41 to 45 years. Near about two-third of the respondents (64 per cent) were married. More than one-third of the respondents' (42.2 per cent) monthly incomes were between Tk. 80000-Tk. 100000. More than 80 percent of the respondents were found Muslims.

\section{Analysis and Findings}

\subsection{Measures}

Green Perceived value was measured by four items adapted from Chen \& Chang, (2012), whereas; perceived consumer effectiveness was measured by three items from the study of Kang, Liu \& Kim, (2013). Furthermore, environmental knowledge was measured through five items adapted from (Mostafa, 2007). Lastly, dependent variable which is the customers hotel visit intention was measured by three items adapted from Han et al. (2010) The respondents were asked to responded through using a 5-point Likert-type scale ( $1=$ 'strongly disagree'; 5 = 'strongly agree').

\subsection{Measurement Model}

The present study used structural equation modelling approach through partial least square method (PLS) to verify the causal relationships among and between the constructs (Hair et. al., 2013). As a part of analysis, both convergent and discriminant validity were employed to assess and examine the measurement model through AVE, Factor loadings and CR. The study used composite reliabilities for reliability test and average variance extracted (AVE) and factor loadings for assessing convergent validity. The values of all the item loadings of all the constructs were equal or more than 0.6 which is sufficient as recommended by Hair et. al., 2013. According to the same authors, the recommended values for CR and AVE were 0.7 and 0.5 respectively. The result of the measurement model found all the values of AVE higher than 0.5 which is considered adequate for the study. Moreover, all the values of CR were found higher than 0.7 as shown in the table 1 . 
Table 1. Measurement Model

\begin{tabular}{|c|c|c|c|c|}
\hline Constructs & Measurement Items & Loading & AVE & CR \\
\hline \multirow[t]{5}{*}{ Environmental knowledge } & EK 1 & 0.738 & 0.569 & 0.868 \\
\hline & EK 2 & 0.821 & & \\
\hline & EK 3 & 0.798 & & \\
\hline & EK 4 & 0.747 & & \\
\hline & EK 5 & 0.657 & & \\
\hline \multirow[t]{3}{*}{ Intention to visit hotels } & IVGH 1 & 0.922 & 0.790 & 0.919 \\
\hline & IVGH 2 & 0.908 & & \\
\hline & IVGH 3 & 0.835 & & \\
\hline \multirow[t]{3}{*}{ Perceived effectiveness } & PE 1 & 0.814 & 0.588 & 0.810 \\
\hline & PE 2 & 0.699 & & \\
\hline & PE 3 & 0.783 & & \\
\hline \multirow[t]{4}{*}{ Green Perceived value } & GPV 1 & 0.832 & 0.633 & 0.873 \\
\hline & GPV 2 & 0.854 & & \\
\hline & GPV 3 & 0.795 & & \\
\hline & GPV 4 & 0.691 & & \\
\hline
\end{tabular}

The current study then measured discriminant validity to identify the correlations among the constructs. Fornell \& Larcker (1981) stated that discriminant validity is the comparison of the relationships between the individual constructs and particular AVE's square root. The outcome of the discriminant validity showed that the result was significant as all the diagonal values found higher than their off-diagonal values (see table 2). As shown in the following table, the calculated values of all the AVEs are higher than the inter-correlations of the diagonal values with other off-diagonal constructs which ensures that the model used in this study has sufficient convergent and discriminant validity.

Table 2. Discriminant Validity Table

\begin{tabular}{lcccc}
\hline & EK & IVGH & PE & PV \\
\hline Environmental knowledge & $\mathbf{0 . 7 5 4}$ & & & \\
Intention to visit green hotels & 0.314 & $\mathbf{0 . 8 8 9}$ & $\mathbf{0 . 7 6 7}$ & \\
Perceived effectiveness & 0.448 & 0.479 & 0.558 & $\mathbf{0 . 7 9 5}$ \\
Perceived value & 0.649 & 0.406 & 3.82 & 3.74 \\
Mean & 3.78 & 3.84 & 0.71 & 0.77 \\
S.D & 0.69 & 0.72 & &
\end{tabular}

\subsection{Structural Model}

In the current study, Structural model was used to identify the possible cause and effect relationships between and among the constructs. The value of $\mathrm{R}^{2}$ specifies path coefficients, whereas, the value of $\beta$ and $t$-values show the significance level of the research hypotheses (Chin, 2010). A 1000 re-sampling was considered for bootstrapping in assigning a structural model to test the path coefficient (Chin, 2010). $\mathrm{R}^{2}$ was found to be $27.0 \%$ for intention to visit green hotel by perceived effectiveness and perceived green value. From the result of the analysis, two exogenous variable (perceived effectiveness and perceived green value) showed significant positive relationship with the endogenous variable (intention to visit green hotel). As shown in the table 3, In the direct relationship between the variables, both the direct path of Green perceived value to green hotel visit intention and perceived consumer effectiveness to green hotel visit intention were found statistically significant and the values were $(\beta=0.362, t=5.096)$ and $(\beta=0.183, t=2.469)$ respectively. On the other hand the moderating variable environmental knowledge showed insignificant effect between perceived effectiveness, perceived green value and intention to visit green hotel. Table 3 provides the outcome the hypothetical result.

\section{Discussion}

The current study attempts to test the effect customers green perceived value and Perceived Consumer effectiveness on customers' intention to visit green hotels with the moderating effect of environmental knowledge in the hotel industry of Bangladesh. This study mainly focuses on the luxury hotel customers of Bangladesh to explore the intention of the customers to visit environmentally conscious hotels. From the result of the study, it can be inferred that customers green perceived value and perceived effectiveness enhances the intention of the customers to visit hotels that are environmentally and ecologically responsible. Findings of the study showed that there is significant direct influence of green perceived value on customers' hotel visit intention. The significant positive result suggests that increasing green perceived value can not only enhance green consumerism and environmentalism, but also influence customers green purchase intention (green hotel visit intention). The result also found consistent with the previous study (Chen \& Chang, 2012). 
Table 3. Results of the structural path analysis

\begin{tabular}{|c|c|c|c|c|}
\hline Direct Path & Std. Beta & $\begin{array}{l}\text { Std. } \\
\text { Error }\end{array}$ & t-Value & Decision \\
\hline Perceived Effectiveness > Intention to Visit Green Hotel & 0.362 & 0.071 & $5.096 * *$ & Supported \\
\hline Perceived Green Value > Intention to Visit Green Hotel & 0.183 & 0.074 & $2.469 * *$ & Supported \\
\hline \multicolumn{5}{|c|}{ Note: $* * p<0.01, * p<0.05$, (based on One-tailed test with 1000 bootstrapping) } \\
\hline Moderating Path & Std. Beta & $\begin{array}{l}\text { Std. } \\
\text { Error }\end{array}$ & t-Value & Decision \\
\hline $\begin{array}{c}\text { Perceived Effectiveness } * \text { Environmental Knowledge > Intention to } \\
\text { Visit Green Hotel }\end{array}$ & -0.015 & 0.090 & 0.161 & $\begin{array}{c}\text { Not } \\
\text { supported }\end{array}$ \\
\hline $\begin{array}{c}\text { Perceived Green Value * Environmental Knowledge > Intention to Visit } \\
\text { Green Hotel }\end{array}$ & -0.130 & 0.056 & 2.333 & $\begin{array}{l}\text { Not } \\
\text { supported }\end{array}$ \\
\hline
\end{tabular}

Note: $* * \mathrm{p}<0.01, * \mathrm{p}<0.05$, (based on One-tailed test with 1000 bootstrapping)

The effect of perceived consumer effectiveness on customers visit intention was found significant which indicates that if customers believe that they can address the environmental issues through the consumption of green products and services, their willingness to purchase those products or services will likely to increase. The result is consistent with the outcome of some previous study (Kim \& Choi, 2005; Vermeir \& Verbeke, 2008). From the review of the literature and the outcome of the study, we can conclude that there is a strong impact of perceived effectiveness on customers' green purchase intention which suggests that customers are sensitive and concerned about the influence of their consumption behaviour on society and environment. It can also be said that customers behave rationally while they are evaluating the benefits of their green purchase behaviours; eventually, customers may consider their effort to address various social and environmental problems and realize how their consumption behaviours can make distinguished difference to the sustainability of the environment.

The current study extended the previous research by considering environmental knowledge as a moderator variable. However, the moderator hypotheses were found insignificant suggesting that environmental knowledge have no impact on the relationship between green perceived value and green hotel visit intention and perceived effectiveness and green hotel visit intention. The result of the current study found inconsistent with previous literature (Fraj-Andrés \& Martínez-Salinas 2007). The insignificant outcome may happen due the lack of knowledge among the customers regarding the positive outcome of green application to the organization as well as to the society. An increase in knowledge about environmental problems may raise peoples' concern and awareness however; it does not necessarily result in behavioural changes (Bamberg \& Möser, 2007). That means, from the result of the current study we can infer that only customers basic understanding and knowledge regarding environmental issues, green practices and ecological problems may not sufficient to increase the motivation of the customers to adopt sustainable and green consumption practices.

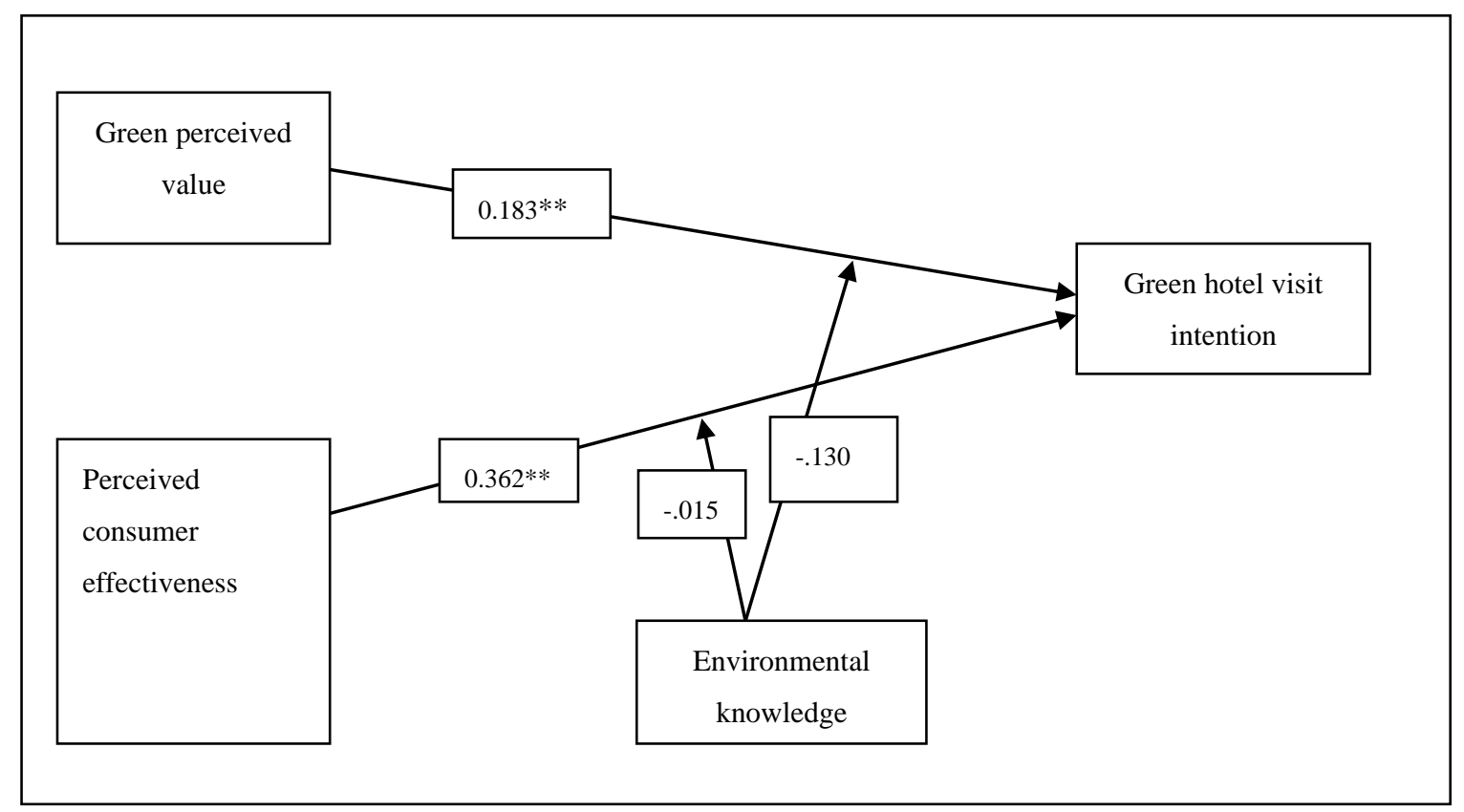

Figure 2. Structural model 


\section{Implications}

From the perspective of theoretical implications, the current study combines the concept of green perceived value, perceived consumer effectiveness and environmental knowledge o develop a research framework of green purchase intentions in the context of Bangladesh. Therefore, this paper may assist as a ground for the future researchers regarding green hotel visit intention in the context of developing countries. The current study considers a conceptual framework demonstrating the relationships among green perceived value, perceived consumer effectiveness and green hotel visit intention with a moderating effect of environmental knowledge.

The findings of the current study also have several managerial implications for the policy development and implementations regarding green hotels. Organizations, managers, policy makers and hotel owners in general should increase perceived value regarding green hotels which in turn may increase customers visit intention. Effective starting point for the marketers and policy owners might be to develop strategies in order to increase the perceptions of functional, social, emotional, conditional etc values regarding green products. Therefore, based on the outcome of this research, it can be suggested that marketers should give more emphasis on customers' value perception as a part of green marketing efforts to encourage green hotel visit intention and to enhance ecological balance. Furthermore, the empirical results of the current study revealed that customers are concerned about the effects of their consumption pattern and behaviour on society and environment at large. Moreover, customers are sensitive towards the fact that how their purchasing pattern and efforts can make a difference and can protect the environment. Through effective promotional programs and strategies, green marketers should encourage customers' perceived effectiveness regarding green products and make them feel that their efforts, consumption patterns and attitude can protect the environmental sustainability.

\section{Limitations and Future Research Suggestions}

There are few research limitations of the current study. Firstly, as the study focused only on the customers of Bangladesh, generalizing the outcome of the study will be doubtful. Therefore, future researchers may focus on the customers of other developing countries and can compare with the current study. Secondly, the current study concentrated only on the hotel industry of Bangladesh as customers' green hotel visit intention was explored. So, future study can assess the purchase intention and behaviour of other products and services. Finally, from the outcome of the research, the dynamic change of the customers' attitude and behaviour cannot be assessed as the current study applied cross sectional data. Therefore, it is suggested to the future researchers to consider longitudinal data to find out the differences of perceived effectiveness, green perceived value and green hotel visit intention of the customers. These theoretical focuses can enlighten the area of green consumption and environmental sustainability.

\section{Conclusions}

Since Green marketing is becoming a distinguished way of differentiating and positioning, growing number of organizations are becoming environmentally concerned and incorporating the green marketing strategies. Similarly, consumers of this $21^{\text {st }}$ century are showing socially responsible consumption behaviour and becoming more willing to purchase environmental friendly products. Based on the results from this research, companies may increase the level of customers green purchase intention through enhancing green perceived value and perceived consumer effectiveness. Also, it can be suggested to the green marketers to give more attention to the customers' perceived effectiveness as customers think that their efforts may address the social and ecological issues and consider green consumption practices as worthy.

Moreover, the industry professionals have to consider the fact that only a mere understanding of environmental issues and having a greater level of knowledge will not let the customers to adopt green consumerism practices. Rather, the industry professionals, marketers and policy makers will have to motivate and encourage the customers to adopt green consumption behaviour through providing firm level of perceived value and effectiveness. The findings of the current study will help marketing managers to develop appropriate strategies to design and stage operational processes for incorporating green marketing strategies on how to induce customers visit intention. The findings and analysis of the present study may consider as an emerging step toward increasing green purchase intention and enhancing green consumption behaviour. It can be suggested to the management well as the regulatory body of hotel industry in Bangladesh to give more attention about the application of green concept and responsible to the environment. Therefore, the current study will be helpful for the industry professionals and policy makers to formulate and develop more effective green marketing strategies and actions to enhance green purchase intention among Bangladeshi customers. 


\section{References}

Ashton, A. S., Scott, N., Solnet, D., \& Breakey, N. (2010). Hotel restaurant dining: The relationship between perceived value and intention to purchase. Tourism and Hospitality Research, 10(3), 206-218. https://doi.org/10.1057/thr.2010.5

Asia's Media and Marketing Newspaper. (2008, April 3). Green Marketing Makes Its Asian Debut. Opinion 1, p. 22.

Bamberg, S., \& Möser, G. (2007). Twenty years after Hines, Hungerford, and Tomera: A new meta-analysis of psycho-social determinants of pro-environmental behaviour. Journal of Environmental Psychology, 27(1), 14-25. https://doi.org/10.1016/j.jenvp.2006.12.002

Bangladesh Parjatan Corporation, 2015. A report on the increasing number of tourist. Available at https://en.wikipedia.org/wiki/Bangladesh_Parjatan_Corporation

Bangladesh Tourism Board, 2014. Tourism Guide for the tourists in Bangladesh. Available at http://www.mediafire.com/file/ion47ymod1hhd6l/Tourist+Handbook.pdf

Bangladesh Tourism Board, 2017. Tourism Guide for the tourists in Bangladesh. Available at http://www.mediafire.com/file/ion47ymod1hhd6l/Tourist+Handbook.pdf

Brady, M. K., \& Robertson, C. J. (1999). An exploratory study of service value in the USA and Ecuador. International Journal of Service Industry Management, 10(5), 469-486. https://doi.org/10.1108/09564239910289003

Carroll, A., \& Buchholtz, A. (2014). Business and society: Ethics, sustainability, and stakeholder management. Nelson Education.

Chan, R. Y., \& Lau, L. B. (2000). Antecedents of green purchases: a survey in China. Journal of consumer marketing, 17(4), 338-357. https://doi.org/10.1108/07363760010335358

Chang, H., \& Wen, C. S. (2008). The impact of online store environment cues on purchase intention: Trust and perceived risk as a mediator. Online information review, 32(6), 818-841. https://doi.org/10.1108/14684520810923953

Chen, Y. S., \& Chang, C. H. (2012). Enhance green purchase intentions: The roles of green perceived value, green perceived risk, and green trust. Management Decision, 50(3), 502-520. https://doi.org/10.1108/00251741211216250

Chin, W. W., \& Dibbern, J. (2010). Handbook of partial least squares. How to write up and report PLS analyses. New York: Springer, 655-690. https://doi.org/10.1007/978-3-540-32827-8_29

Chou, C. J., Chen, K. S., \& Wang, Y. Y. (2012). Green practices in the restaurant industry from an innovation adoption perspective: Evidence from Taiwan. International Journal of Hospitality Management, 31(3), 703-711. https://doi.org/10.1016/j.jihm.2011.09.006

Connell, K. Y. H. (2010). Internal and external barriers to eco-conscious apparel acquisition. International Journal of Consumer Studies, 34(3), 279-286. https://doi.org/10.1111/j.1470-6431.2010.00865.x

Cronin, J. J., Brady, M. K., Brand, R. R., Hightower Jr, R., \& Shemwell, D. J. (1997). A cross-sectional test of the effect and conceptualization of service value. Journal of services Marketing, 11(6), 375-391. https://doi.org/10.1108/08876049710187482

Curlo, E. (1999). Marketing strategy, product safety, and ethical factors in consumer choice. Journal of Business Ethics, 21(1), 37-48. https://doi.org/10.1023/A:1005973306941

Eze, U. C., \& Ndubisi, N. O. (2013). Green buyer behavior: Evidence from Asia consumers. Journal of Asian and African Studies, 48(4), 413-426. https://doi.org/10.1177/0021909613493602

Fornell, C., \& Larcker, D. F. (1981). Evaluating structural equation models with unobservable variables and measurement error. Journal of marketing research, 39-50. https://doi.org/10.1177/002224378101800104

Fraj-Andrés, E., \& Martínez-Salinas, E. (2007). Impact of environmental knowledge on ecological consumer behaviour: an empirical analysis. Journal of International Consumer Marketing, 19(3), 73-102. https://doi.org/10.1300/J046v19n03_05

Gleim, M. R., Smith, J. S., Andrews, D., \& Cronin Jr, J. J. (2013). Against the green: a multi-method examination of the barriers to green consumption. Journal of retailing, 89(1), 44-61. https://doi.org/10.1016/j.jretai.2012.10.001 
Gounaris, S. P., Tzempelikos, N. A., \& Chatzipanagiotou, K. (2007). The relationships of customer-perceived value, satisfaction, loyalty and behavioural intentions. Journal of Relationship Marketing, 6(1), 63-87. https://doi.org/10.1300/J366v06n01_05

Green Hotels Association. (2010).What are green hotels? Retrieved from http:// greenhotels.com/index.php\#a

Gupta, S., \& Ogden, D. T. (2009). To buy or not to buy? A social dilemma perspective on green buying. Journal of Consumer Marketing, 26(6), 376-391. https://doi.org/10.1108/07363760910988201

Gustin, M. E., \& Weaver, P. A. (1996). Are hotels prepared for the environmental consumer? Hospitality Research Journal, 20(2), 1-14. https://doi.org/10.1177/109634809602000201

Hair, J. F., Ringle, C. M., \& Sarstedt, M. (2013). Partial least squares structural equation modelling: Rigorous applications, better results and higher acceptance. https://doi.org/10.1016/j.lrp.2013.01.001

Han, H., Hsu, L. T. J., \& Sheu, C. (2010). Application of the theory of planned behaviour to green hotel choice: Testing the effect of environmental friendly activities. Tourism management, 31(3), 325-334. https://doi.org/10.1016/j.tourman.2009.03.013

Harris, P. G. (2006). Environmental perspectives and behaviour in China: Synopsis and bibliography. Environment and behaviour, 38(1), 5-21. https://doi.org/10.1177/0013916505280087

Jones, P., Comfort, D., \& Hillier, D. (2014). Sustainability in the Global Hotel Industry', International Journal of Contemporary Hospitality Management', 26(1), 5-17. https://doi.org/10.1108/IJCHM-10-2012-0180

Kang, J., Liu, C., \& Kim, S. H. (2013). Environmentally sustainable textile and apparel consumption: the role of consumer knowledge, perceived consumer effectiveness and perceived personal relevance. International Journal of Consumer Studies, 37(4), 442-452. https://doi.org/10.1111/ijcs.12013

Kardes, F. R., Posavac, S. S., \& Cronley, M. L. (2004). Consumer inference: A review of processes, bases, and judgment contexts. Journal of Consumer Psychology, 14(3), 230-256. https://doi.org/10.1207/s15327663jcp1403_6

Kim, Y., \& Choi, S. M. (2005). Antecedents of green purchase behaviour: An examination of collectivism, environmental concern, and PCE. ACR North American Advances.

Kim, Y., \& Han, H. (2010). Intention to pay conventional-hotel prices at a green hotel-a modification of the theory of planned behavior. Journal of Sustainable Tourism, 18(8), 997-1014. https://doi.org/10.1080/09669582.2010.490300

Manaktola, K., \& Jauhari, V. (2007). Exploring consumer attitude and behaviour towards green practices in the lodging industry in India. International Journal of Contemporary Hospitality Management, 19(5), 364-377. https://doi.org/10.1108/09596110710757534

Millar, M., \& Baloglu, S. (2011). Hotel guests' preferences for green guest room attributes. Cornell Hospitality Quarterly, 52(3), 302-311. https://doi.org/10.1177/1938965511409031

Mostafa, M. M. (2007). Gender differences in Egyptian consumers' green purchase behaviour: the effects of environmental knowledge, concern and attitude. International Journal of Consumer Studies, 31(3), 220-229. https://doi.org/10.1111/j.1470-6431.2006.00523.x

Padel, S., \& Foster, C. (2005). Exploring the gap between attitudes and behaviour: Understanding why consumers buy or do not buy organic food. British Food Journal, 107(8), 606-625. https://doi.org/10.1108/00070700510611002

Rex, E., \& Baumann, H. (2007). Beyond ecolabels: what green marketing can learn from conventional marketing. Journal of cleaner production, 15(6), 567-576. https://doi.org/10.1016/j.jclepro.2006.05.013

Roberts, J. A. (1996). Green consumers in the 1990s: profile and implications for advertising. Journal of business research, 36(3), 217-231. https://doi.org/10.1016/0148-2963(95)00150-6

Rubel, M. R. B., \& Kee, D. M. H. (2014). Quality of work life and employee performance: Antecedent and outcome of job satisfaction in Partial Least Square (PLS). World Applied Sciences Journal, 31(4), 456-467.

Siegenthaler, J. P. (2010, June). How Green Are Your Customers? Supply House Times, pp. 41-42.

Sloan, P., Legrand, W., \& Simons-Kaufmann, C. (2014). A survey of social entrepreneurial community-based hospitality and tourism initiatives in developing economies: A new business approach for industry. Worldwide Hospitality and Tourism Themes, 6(1), 51-61. https://doi.org/10.1108/WHATT-11-2013-0045 
Smith, S., \& Paladino, A. (2010). Eating clean and green? Investigating consumer motivations towards the purchase of organic food. Australasian Marketing Journal (AMJ), 18(2), 93-104.

https://doi.org/10.1016/j.ausmj.2010.01.001

Smith, T. (2008). Billion Dollar Green: Profit from the Eco Revolution. John Wiley \& Sons.

Vermeir, I., \& Verbeke, W. (2008). Sustainable food consumption among young adults in Belgium: Theory of planned behaviour and the role of confidence and values. Ecological Economics, 64(3), 542-553. https://doi.org/10.1016/j.ecolecon.2007.03.007

Vora, S. (2007). Business travelers go green. Retrieved February, 20, 2014.

Wolff, C. (2008). Second Nature. Lodging Hospitality, 64(2), 24-26

\section{Copyrights}

Copyright for this article is retained by the author(s), with first publication rights granted to the journal.

This is an open-access article distributed under the terms and conditions of the Creative Commons Attribution license (http://creativecommons.org/licenses/by/4.0/). 